\title{
Knowledge, attitude, and practice towards COVID-19 among university students in Indonesia: A cross-sectional study
}

\author{
Sulistyawati Sulistyawati ${ }^{1}$, Muhammad Syamsu Hidayat ${ }^{2}$, Siwi Pramatama Mars Wijayanti ${ }^{3}$, Tri \\ Wahyuni Sukesi $^{4}$, Siti Kurnia Widi Hastuti ${ }^{5}$, Surahma Asti Mulasari ${ }^{6}$, Fatwa Tentama ${ }^{7}$, Rokhmayanti \\ Rokhmayanti $^{8}$, Ulinnuha Yudiansa Putra', Sitti Nur Djannah ${ }^{10}$ \\ 1,2,4,5,6,8,10 Faculty of Public Health, Universitas Ahmad Dahlan, Yogyakarta, Indonesia \\ ${ }^{3}$ Department of Public Health, Faculty of Health Sciences, University of Jenderal Soedirman, Purwokerto, Indonesia \\ ${ }^{7}$ Faculty of Psychology, Universitas Ahmad Dahlan, Yogyakarta, Indonesia \\ ${ }^{9}$ Faculty of Economics and Business, Universitas Ahmad Dahlan, Yogyakarta, Indonesia
}

\begin{tabular}{l} 
Article Info \\
\hline Article history: \\
Received May 5, 2021 \\
Revised Aug 11, 2021 \\
Accepted Aug 23, 2021 \\
\hline
\end{tabular}

Keywords:

COVID-19

KAP

Risk factor

University student

\begin{abstract}
The presence of asymptomatic people exacerbates the widespread Coronavirus disease (COVID-19) transmission. The majority of them come from young people. This study aimed to explore the knowledge, attitude, and practice related to COVID-19 among university students in Indonesia, and the potential factor influenced their knowledge. A cross-sectional study involved 1,427 university students were carried out using an online survey from March 28 to April 10, 2020. A structured questionnaire consist of six sections focuses on knowledge, attitude, and preventive measure related to COVID-19 was used to collect the data. The analysis was performed using descriptive, Mann-Whitney, and Kruskal-Wallis tests. Results of the analysis indicated a significant difference in terms of mean between males and females regarding knowledge about preventing and protect others from COVID-19, the risk factor of getting COVID-19 infection, and knowledge that COVID-19 is curable. Knowledge total score among the respondent, there was a significant difference within the research group. This study demonstrates that the respondent has a basic knowledge about COVID-19 and the proper attitude, but it seems they are not consistent on practice in a particular measure.
\end{abstract}

This is an open access article under the CC BY-SA license.

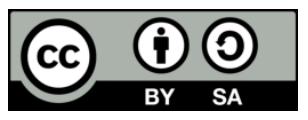

\section{Corresponding Author:}

Sulistyawati Sulistyawati

Faculty of Public Health

Universitas Ahmad Dahlan

Jl Prof Dr Soepomo, Janturan, Umbulharjo, Yogyakarta 55164, Indonesia

Email: sulistyawati.suyanto@ikm.uad.ac.id

\section{INTRODUCTION}

Coronavirus disease (COVID-19) is a significant infectious disease nowadays, given that more than two hundred million of the world's societies are infected with this disease, among which 4,430,697 people died per August 23, 2021 [1]. While in Indonesia, 10,551 confirmed cases were reported, with 800 mortality per May 1, 2020 [2]. According to WHO, COVID-19 is caused by severe acute respiratory syndrome coronavirus 2 (SARS Cov-2), a new coronavirus that was first identified in Wuhan, China, last December 2019 [3]. SARS-CoV-2 is considered a novel Betacoronavirus, which infects humans [4]. SARS-CoV-2 genome phylogenetic analysis suggests that the virus is closely related (with 88 percent identity) to two batderived SARS-like coronaviruses collected in eastern China in 2018 (bat-SL-CoVZC45 and bat-SLCoVZXC21) and genetically distinct from SARS-CoV (with approximately 79 percent similarity) and 
MERS-CoV [5]. Symptoms of infection with COVID-19 occur after an incubation time of around 5.2 days. The onset of COVID-19 symptoms to death varied from 6 to 41 days, with a 14-day median. The time depends on the patient's age and the state of the patient's immune system [6].

People infected with COVID-19 will commonly show symptoms such as having fever, feeling tired, and having a dry cough [7]. Nevertheless, others have experienced severe clinical signs such as dyspnea and critical illness: such as respiratory failure, septic shock and/or multiple organ dysfunction (MOD) or failure (MOF). In 5\% of cases, this critical manifestation occurred [8]. COVID-19 transmitted through droplets from the nose or mouth produced by a person infected with COVID-19 coughs or exhales [9]. Droplets could fall on any surface and be touched by people who then transmitted through their eyes, nose, or mouth [10], [11]. It is also believed in recent research developments that COVID-19 can be transmitted via airborne transmission. This means that the virus can be transmitted by inhaling microscopic droplets produced by breathing, talking, singing, and not just coughing and sneezing [12]. Therefore, maintain physical distance among people is mandatory to avoid the virus transported across the individual. It is suggested that the interpersonal distance of two meters can be an effective protection effort only if everybody wears face masks for their daily life activities [13].

This new virus is very contagious and has spread rapidly worldwide. Indonesia announced COVID19 case for the first time at the beginning of March 2020 [14], [15]. Since then, positive cases have increased considerably. The government has implemented several efforts to reduce morbidity and mortality. However, this effort cannot stand alone and requires public supports. The Indonesian government rolled out a policy of social restriction through working and learning from home. The policy has both given positive and negative impacts. On the one hand, this policy supports social and physical distancing, which prevents COVID-19 transmission. On the contrary, public compliance to COVID-19 preventive measures during their stay at home is not well understood and challenging to control. One particular population group vulnerable to this situation is university students since many are away from their hometowns. They are a very dynamic group with high movement in their daily lives that may put them at increased risk to COVID-19. They can also have asymptomatic COVID-19 infections, thereby increasing their chances of becoming a source of transmission. A previous study stated that these young people had a rapid onset and various non-specific atypical manifestations and much milder than in older patients [16].

Young people are one of the target groups on COVID-19 prevention because they could be infected and be sources of transmission but with mild or no symptoms [17]. Older families or other people with comorbid diseases [18]. Incidents in countries like Italy show the potential for such transmission. And even if it is infected, the signs are just mild infections, but a mild COVID-19 infection can have long-term health implications [19]. Some of the health effects that can arise are severe fatigue, shortness of breath, and difficulties resuming daily activity, as some of the long-term effects can be encountered by those with mild infections [20]. Therefore, knowledge and awareness related to prevention are crucial in the young adult group [16].

Knowledge, attitude, and practice (KAP) are the capital of health promotion to achieve health prevention success. Numerous researches have applied this approach in determining the appropriate intervention for people in various disease settings [21]-[25]. However, for COVID-19, which was recently discovered, the KAP assessment related to the disease, particularly in young adults, is still rare. This research explores the knowledge, attitude, and practice regarding COVID-19 among university students in Indonesia and the potential factors influencing the knowledge. This study's findings would provide an overview of young people's awareness and attitudes towards COVID-19; therefore, appropriate strategies can be made for this specific age group.

\section{RESEARCH METHOD}

\subsection{Study design and participants}

A cross-sectional study was carried out to assess KAP and several factors related to COVID-19 among students across Indonesia. Online surveys by using questionnaires were conducted to collect the data. Our inclusion criteria for the participant were active scholars to any degree, including professional education. People who fit with our criteria could self-enrollment through the link and fill out the informed consent before the survey started. This study involves 1,427 students from 24 provinces in Indonesia.

\subsection{Research instrument}

This survey used a structured questionnaire developed by the research group. Prior to the survey, the questionnaire has been validated by an expert in the health behaviour field. The questionnaire was divided into five sections: i) information for participant and informed consent; ii) personal information: email address, sex, age, university and faculty name, education degree and their semester, hometown, living with 
whom, travelling history in 14 days; iii) knowledge about COVID-19: COVID-19 symptoms and transmissions, prevention knowledge, COVID-19 risk factors; iv) attitude related to COVID-19: COVID-19 information sources, perception about the level of seriousness of COVID-19; v) practice towards COVID-19: Not going out of the town, measure when having COVID-19 symptoms.

\subsection{Data collection and analysis}

Google form link was distributed to our networks in many WhatsApp groups and social media platforms to reach the participant from March 28 to April 10, 2020. Data were analyzed using Statistical Package for Social Science (SPSS). Socio-demographic characteristics of respondents, attitudes, and practices were analyzed descriptively. In knowledge-related COVID-19, we scored a correct answer with one wrong answer with 0; then, we calculated each question item. Mann-Whitney and Kruskal-Wallis were used to compare mean within the group and knowledge items.

\subsection{Ethical considerations}

The study was approved by the Ethical Review Board of Universitas Ahmad Dahlan, Yogyakarta, Indonesia (ethical approval code: 012003015).

\section{RESULTS AND DISCUSSION}

We received 1,444 valid responses. Seventeen of them were excluded because they stated they were not willing to participate or are Indonesians who live abroad, so they were not experienced with the pandemic situation in 1,427 responses that included in the analysis. Table 1 describes respondents' socio-demographic characteristics. The majority (78.6\%) were female, with male student's accounts for less than $22 \%$. The extremely skewed gender response partly reflects the gender ratio among undergraduate students where in this study account, $72 \%$ in Indonesia, with more than half are currently female [26]. This phenomenon corresponds with a study conducted by Smith that showed younger age groups and females' tendency to be more eager to take part in online surveys [27]. More than $90 \%$ of the respondents were aged between 17-25 years old. $72 \%$ of our respondents finished undergraduate education, followed by diploma education about $21 \%$.

Table 1. Sociodemographic characteristics of respondent $(n=1,427)$

\begin{tabular}{lcc}
\hline \multicolumn{1}{c}{ Variables } & Number & Percentage (\%) \\
\hline Gender & & \\
- Male & 306 & 21.4 \\
- Female & 1,121 & 78.6 \\
Age & & \\
- 17-25 & 1,367 & 95.8 \\
- 26-35 & 33 & 2.3 \\
- 36-49 & 27 & 1.9 \\
Education degree & & \\
- Doctoral & 8 & 0.6 \\
- Masters & 47 & 3.3 \\
- Undergraduate & 1,028 & 72.0 \\
- Diploma & 3104 & 0.321 .7 \\
- Professional education & 34 & 2.4 \\
\hline
\end{tabular}

Figure 1 illustrates the distribution of respondents according to their university location. Our respondents came from campuses in 24 provinces out of 34 provinces in Indonesia. Most of our respondents, 540 (37.8\%), were from universities in Yogyakarta province, followed by Central Java, with $363(25.4 \%)$ respondents. Nearly $75 \%$ of our respondents are currently studying in universities in Java. However, it does not mean that they come from Java as many students in Java were from other islands but decided to study in Java to seek better education. 


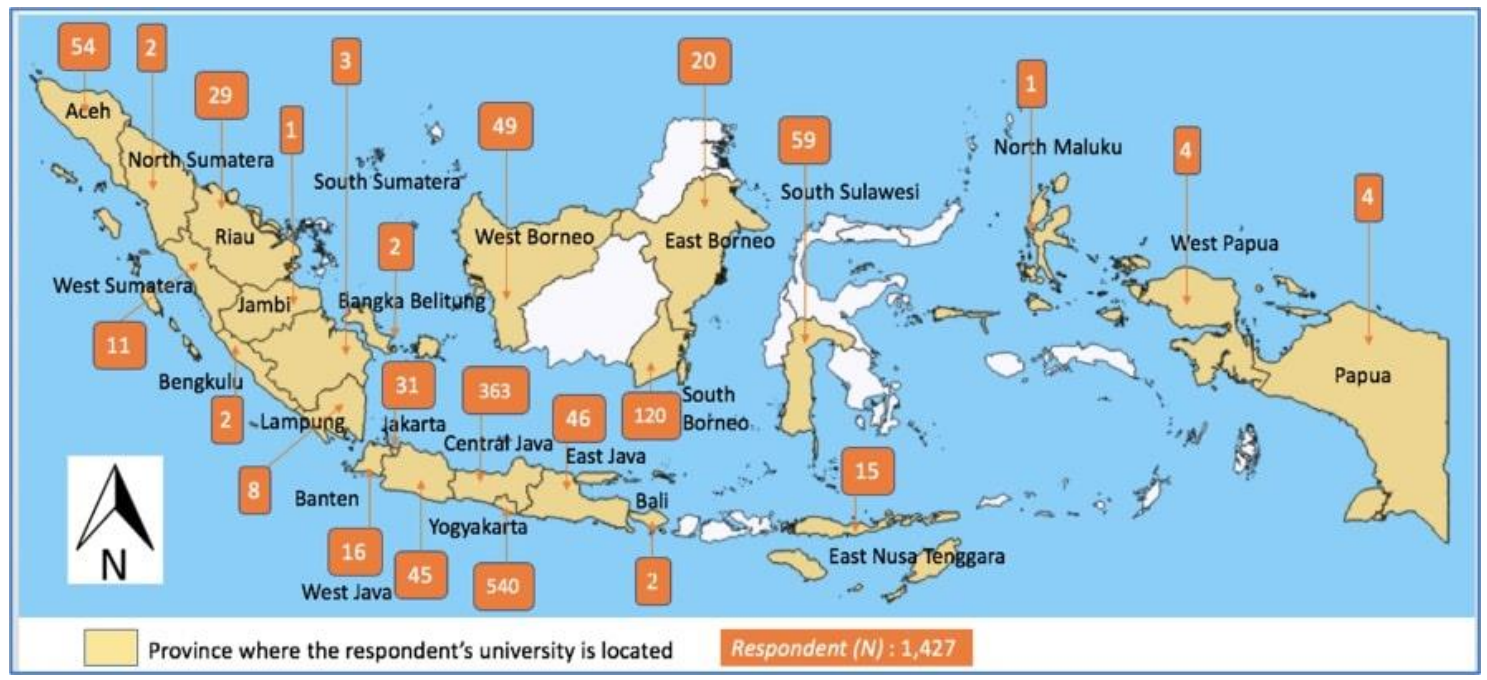

Figure 1. Distribution of respondents according to their university location

Knowledge, attitude, and practice are presented in Table 2. The majority of respondents recognized initial symptoms of COVID-19, such as having fever $38^{\circ} \mathrm{C}$ or more $(90.2 \%)$, having cough $(88.0 \%)$, having shortness of breath (92.5), and having flu and colds $(61.6 \%)$. In terms of people contracting coronavirus infection, more than $80 \%$ of respondents knew that droplets from coughing and sneezing from people infected with COVID-19 virus, physical contact or shake hands with people infected by COVID-19 virus and/or touching objects and surfaces contaminated by COVID-19 virus could cause coronavirus infections. Other modes of coronavirus transmission such as person to person, mosquito bites, fecal contamination and coronavirus as an airborne disease were supported by $95.4 \%, 1.1 \%, 6.8 \%$, and $29.2 \%$ respondents, respectively. To prevent and protect from COVID-19, most respondents suggested avoiding contact with patients with acute or unhealthy respiratory diseases $(82.2 \%)$, washing hands frequently with soap or hand sanitizer (97.0\%), improving body's immunity (95.0\%), and avoid touching one's face area without washing hands first $(93.1 \%)$. While avoiding contact with farm and wild animals without protection was reported by $(45.4 \%)$ of the respondent.

The respondents in this study seem to have a thorough knowledge of COVID-19 risk factors. The primary source of information came from social media and/or the internet, and less reliance on a more 'traditional' source of information such as family, lecturer, and health staff. More than $90 \%$ of respondents knew that travelling to areas with local transmission and having physical contact with patients under supervision or positive could increase the risk of contracting COVID-19. Among the respondents, nearly three-quarters understood that working or visiting health facilities is also a risk factor. On the contrary, other practices such as living a healthy lifestyle, practising physical distancing, and having good immunity were not considered risk factors, with only $2.9 \%, 3.5 \%$, and $1.3 \%$ of respondents, respectively, considered those practices risk factors.

Most respondents in this study treated COVID-19 very seriously. Nearly all respondents considered COVID-19 as very serious (97.0\%). A high proportion of the respondents also believed that the level of COVID-19 spreading in Indonesia is severe (95.5\%), a stark contrast with the Indonesian government - at least in the early stage-often criticizedc as ignorant and responding insufficiently. The central government's initially slow response seems to dissuade more substantial public support as more respondents rate public awareness as somewhat serious (61.1\%) and not serious (20\%) rather than very serious (18.9\%).

As for issues in averting the spread of COVID-19, many of the respondents $(72.3 \%)$ chose to restrain from travellingout of the town. In the case of having COVID-19 symptoms, most respondents $(85.7 \%)$ planned to go to health facilities to get tested, while less than half prefer to stay at homes $(45.4 \%)$. It is unclear why they chose to stay at home, but it is likely due to concern over patients' overflowing in several hospitals, insufficiency of health facilities, and public stigma. Also prevalent among the young age group the majority in this study-was the conviction that the disease is curable (98.5\%), particularly for their specific age groups where the recovery rate is high. 
Table 2. Knowledge, attitude, and practice of respondents

Characteristic

Knowledge toward COVID-19

Initial symptoms when infecting COVID-19*

$\begin{array}{ll}\text { Having a fever of at least 38-degree Celsius } & 1,288 \quad 90.2\end{array}$

$\begin{array}{ll}\text { Having cough } & 88.0\end{array}$

\begin{tabular}{ll} 
Shortness of breath & 92.5 \\
\hline
\end{tabular}

Having flu and colds $\quad 61.6$

The way of people getting COVID-19 infections*

The COVID-19 virus not transmits person to person 4.6

COVID-19 is an airborne disease $\quad 29.2$

COVID-19 virus transmitted by a mosquito biting 1.1

Droplets from coughing and sneezing of people infected with COVID-19 virus $\quad 88.0$

Personal contact, touch or shake hands with positive COVID-19 virus $\quad 83.2$

Touching an object or surface containing the COVID-19 virus, then touching the mouth, nose, or eyes before $1,385 \quad 97.0$

washing your hands

Fecal contamination

Mode to prevent and protect others from COVID-19*

Avoid close contact with patients with acute or unhealthy respiratory diseases

Avoid contact with farms or wild animals without protection

Maintain and improve the body's immunity $\quad 95.0$

Do not touch the eyes, nose, and mouth without washing your hands first $\quad 93.1$

The risk factor of getting COVID-19 infection*

Travelling to an area with COVID-19 local transmission in the last 14 days 97.0

Having a history of contact with confirmed cases of COVID-19 or patients with COVID-19 supervision (PDP)

Applying a clean and healthy lifestyle such as washing hands with soap and running water 42.9

Working or visiting health facilities that handle patients confirmed by COVID-19

Doing social distancing

Having good immunity

Does COVID-19 is curable?

Yes

No

Attitude toward COVID-19

Level of the seriousness of COVID-19

Very serious

Somewhat serious

Not serious

Level of seriousness the spreading of COVID-19 in Indonesia

Very serious

Somewhat serious

Not serious

Level of seriousness on facing COVID-19 among society in Indonesia

Very serious

Somewhat serious

Not serious

Practice toward COVID-19

I am notgoing out of the town within 14 days to avoid COVID-19.

Yes No

lutions when having COVID-19 symptoms*

Going to the health facility

Going to drugstore

Buying herb

Staying at home

VID-19 information source*

Social media (Facebook, Instagram, WhatsApp group) $\quad 93.4$

Internet

Television

Family, friends, neighbours, college

Lecturer

*Respondent was allowed to take more than one choice

Based on the Mann-Whitney and Kruskal Wallis test in Table 3 with $(\alpha=0.05)$, there is a significant difference in the mean of knowledge between males and females on the topic of preventing and protecting others from COVID-19, risk factors of getting COVID-19 infection, and whether COVID-19 is curable. However, there is no difference in mean on initial symptoms when infecting COVID-19 and contracting COVID-19. In all gender groups with a significant difference in mean, the male group has a higher standard than the female. Likewise, age group 26-35 has a significantly higher mean than other age groups regarding preventing and protecting others from COVID-19 and the total score of COVID-19 knowledge, but not on

Knowledge, attitude, and practice towards COVID-19 among university... (Sulistyawati Sulistyawati) 
the other four bits of knowledge. This study found no difference in mean among the eight-level group of education on the level of education.

Table 3. Mean ( \pm SE) knowledge item and total score among the respondent

\begin{tabular}{|c|c|c|c|c|c|c|c|c|c|c|c|c|}
\hline \multirow[t]{2}{*}{$\begin{array}{c}\text { Characteristic } \\
\text { respondent }\end{array}$} & \multicolumn{2}{|c|}{$\begin{array}{c}\text { Knowledge } \\
\text { towards initial } \\
\text { symptoms when } \\
\text { infecting } \\
\text { COVID-19 }\end{array}$} & \multicolumn{2}{|c|}{$\begin{array}{l}\text { Knowledge of } \\
\text { getting COVID- } \\
19 \text { infection }\end{array}$} & \multicolumn{2}{|c|}{$\begin{array}{l}\text { Knowledge } \\
\text { about } \\
\text { preventing and } \\
\text { protect others } \\
\text { from COVID- } \\
19\end{array}$} & \multicolumn{2}{|c|}{$\begin{array}{l}\text { Knowledge } \\
\text { about the risk } \\
\text { factor of getting } \\
\text { COVID-19 } \\
\text { infection }\end{array}$} & \multicolumn{2}{|c|}{$\begin{array}{c}\text { The knowledge } \\
\text { that COVID-19 } \\
\text { is curable }\end{array}$} & \multicolumn{2}{|c|}{$\begin{array}{l}\text { The total score } \\
\text { of COVID-19 } \\
\text { knowledge }\end{array}$} \\
\hline & Mean & $\begin{array}{c}\mathrm{p}- \\
\text { value }\end{array}$ & Mean & $\begin{array}{c}\mathrm{p}- \\
\text { value }\end{array}$ & Mean & $\begin{array}{c}\mathrm{p}- \\
\text { value }\end{array}$ & Mean & $\begin{array}{c}\mathrm{p}- \\
\text { value }\end{array}$ & Mean & $\begin{array}{c}\mathrm{p}- \\
\text { value }\end{array}$ & Mean & $\begin{array}{c}\mathrm{p}- \\
\text { value }\end{array}$ \\
\hline \multicolumn{13}{|l|}{ Gender } \\
\hline Female & $\begin{array}{c}3.34 \pm \\
0.27 \\
3.25 \pm \\
0.59\end{array}$ & 0.58 & $\begin{array}{c}3.04 \pm \\
0.02 \\
3.07 \pm \\
0.04\end{array}$ & 0.42 & $\begin{array}{c}4.17 \pm \\
0.02 \\
4.00 \pm \\
0.05\end{array}$ & 0.00 & $\begin{array}{c}2.68 \pm \\
0.01 \\
2.62 \pm \\
0.03\end{array}$ & 0.01 & $\begin{array}{c}0.99 \pm \\
0.00 \\
0.97 \pm \\
0.01\end{array}$ & 0.03 & $\begin{array}{c}14.22 \pm \\
0.06 \\
13.91 \pm \\
0.14\end{array}$ & 0.19 \\
\hline \multicolumn{13}{|l|}{ Age (years) } \\
\hline $17-25$ & $\begin{array}{l}3.32 \pm \\
0.02\end{array}$ & & $\begin{array}{c}3.05 \pm \\
0.02\end{array}$ & & $\begin{array}{c}4.13 \pm \\
0.02\end{array}$ & & $\begin{array}{c}2.66 \pm \\
0.01\end{array}$ & & $\begin{array}{c}0.99 \pm \\
0.00\end{array}$ & & $\begin{array}{c}14.15 \pm \\
0.06\end{array}$ & \\
\hline $26-35$ & $\begin{array}{c}3.58 \pm \\
0.14\end{array}$ & 0.12 & $\begin{array}{c}3.18 \pm \\
0.09\end{array}$ & 0.07 & $\begin{array}{c}4.48 \pm \\
0.11\end{array}$ & 0.04 & $\begin{array}{c}2.85 \pm \\
0.06\end{array}$ & 0.49 & $*$ & 0.13 & $\begin{array}{c}15.09 \pm \\
0.22\end{array}$ & 0.02 \\
\hline $36-49$ & $\begin{array}{c}3.22 \pm 0 \\
18\end{array}$ & & $\begin{array}{c}2.63 \pm \\
0.18\end{array}$ & & $\begin{array}{c}3.89 \pm \\
0.22\end{array}$ & & $\begin{array}{c}2.48 \pm 0 \\
15\end{array}$ & & $\begin{array}{c}0.96 \pm \\
0.03\end{array}$ & & $\begin{array}{c}13.19 \pm \\
0.60\end{array}$ & \\
\hline \multicolumn{13}{|c|}{ Education degree } \\
\hline Doctoral & $\begin{array}{c}3.75 \pm \\
0.46\end{array}$ & & $\begin{array}{c}3.00 \pm \\
0.53\end{array}$ & & $\begin{array}{c}4.50 \pm \\
0.53\end{array}$ & & $\begin{array}{c}2.50 \pm 0 \\
75\end{array}$ & & $\begin{array}{c}1.00 \pm 0 \\
00\end{array}$ & & $\begin{array}{c}14.75 \pm \\
1.66\end{array}$ & \\
\hline Magister & $\begin{array}{c}3.49 \pm \\
0.85\end{array}$ & & $\begin{array}{c}2.89 \pm \\
0.93\end{array}$ & & $\begin{array}{c}4.06 \pm \\
0.87\end{array}$ & & $\begin{array}{c}2.79 \pm \\
0.46\end{array}$ & & $\begin{array}{c}0.98 \pm \\
0.14\end{array}$ & & $\begin{array}{c}14.21 \pm \\
2.14\end{array}$ & \\
\hline Undergraduate & $\begin{array}{c}3.31 \pm \\
0.93\end{array}$ & 0.38 & $\begin{array}{c}3.04 \pm \\
0.80\end{array}$ & 0.48 & $\begin{array}{c}4.14 \pm \\
0.90\end{array}$ & 0.35 & $\begin{array}{c}2.69 \pm \\
0.58\end{array}$ & 0.10 & $\begin{array}{c}0.99 \pm \\
0.11\end{array}$ & 0.92 & $\begin{array}{c}14.16 \pm \\
2.19\end{array}$ & 0.99 \\
\hline Diploma & $\begin{array}{c}3.32 \pm \\
0.94\end{array}$ & & $\begin{array}{c}3.08 \pm \\
0.95\end{array}$ & & $\begin{array}{c}4.11 \pm \\
1.03\end{array}$ & & $\begin{array}{c}2.58 \pm \\
0.65\end{array}$ & & $\begin{array}{c}0.98 \pm 0 \\
12\end{array}$ & & $\begin{array}{c}14.08 \pm \\
2.68\end{array}$ & \\
\hline $\begin{array}{c}\text { Professional } \\
\text { education }\end{array}$ & $\begin{array}{c}3.38 \pm \\
0.65 \\
\end{array}$ & & $\begin{array}{c}3.09 \pm \\
0.86 \\
\end{array}$ & & $\begin{array}{c}4.00 \pm \\
0.69 \\
\end{array}$ & & $\begin{array}{c}2.71 \pm \\
0.52 \\
\end{array}$ & & $\begin{array}{c}0.97 \pm \\
0.17 \\
\end{array}$ & & $\begin{array}{c}14.15 \pm \\
1.79\end{array}$ & \\
\hline
\end{tabular}

Currently, the New Corona Virus that causes COVID-19 pandemic draws worldwide attention [28]. The disease has spread across many countries and caused massive casualties within only a few months. In Indonesia, the coronavirus infection trend is similar to that of other countries. It has distorted much of the health system due to the considerable number of hospitalized patients. In the absence of a vaccine and the high cost of hospital treatment, prevention measures such as physical distancing, proper coughing and sneezing hygiene, and handwashing are the best exit strategies to avoid the collapse of the health system overcapacity [29]. This study assessed knowledge, attitude, and practice related to COVID-19 disease and the prevention measure among university students.

Refer to our study; we found the majority of respondents have a basic knowledge of COVID-19. But we also found insufficient knowledge about COVID-19 person-to-person transmission from person to person and people's ignorance to stay at home (reduce mobility). Interestingly, most of the respondents stated that society in Indonesia had a somewhat severe level on facing COVID-19. A higher mean knowledge score was found among respondents aged group between 26-35 years old. Regarding person-to-person COVID-19 transmission, several works of the literature confirmed that the new coronavirus is very likely to be transmitted between people through close contact with people with respiratory disease or direct contact with infected people [30], [31]. The low response to this transmission mode may lead to the wrong direction on the respondent's prevention measure. Yet, it is surprising that when we look into the mode of prevention from the COVID-19 response, most respondents agreed that avoiding closed contact with harmful respiratory diseases is one of the modes of COVID-19 transmission. The two-contrast results may elucidate a particular phenomenon-lack of knowledge about how the spread of COVID-19 leads to fewer people compliance in making prevention efforts. Non-compliance with appeals is often seen as selfish or irresponsible to the individual. However, changing people's behaviour is not as easy as just telling them about their disease risk. This is explained in health behaviour in theoretical models such as the Health Belief Model [32].

To reminder, this research engaged students in university education. They have enormous access to social media as nowadays it becomes a lifestyle for them. Most respondents (more than 90\%) reported that their preferable information source about COVID-19 was social media like Facebook, Instagram, and WhatsApp. It may answer this finding and reveal that social media plays an essential role in influencing 
people's knowledge and behaviour in the current digital media era, as stated by some previous research [33], [34]. Providing COVID-19 prevention messages in various ways through social media is estimated to increase awareness of young adults in carrying out preventive behaviours. The active participation of influencers or public figures engaged in social media is also a critical element in providing effective preventive action examples [35].

The previous study that assesses the publis risk perception of COVID-19 in 10 countries reveals that this disease is considered a severe disease. Perceptions of risk for this disease are related to the willingness of individuals to take preventive measures. Several factors were suggested as significant predictors of COVID19 risk perception, such as personal experience with the virus, individualistic and prosocial beliefs, hearing about the virus from family and friends, confidence in government, research, medical professionals, and personal awareness of government policy [36]. However, $61.1 \%$ of respondents considered the public "only" somewhat serious about facing this disease in Indonesia. This result may also be related to the timing of the research conducted in March 2020, when COVID-19 was just beginning to spread in Indonesia. The perception of this disease may change and develop the disease's spread in an area. This perception of "only somewhat serious" might reflect by the phenomenon that less than half of the respondents stated that they would stay at home if having COVID-19 symptoms. Stay at home is the government campaign to keep social distancing and reduce further transmission [37]. This is supported by almost all universities that implement policies to learn from home by online learning methods to anticipate the spread of COVID-19. These results also recall the importance of educating people about carrying out proper self-quarantine for 14 days after travelling outside the region or the home self-isolation procedure when symptoms turn up, pointing to COVID-19. Individual compliance in carrying out health procedures for the prevention of COVID-19 is critical to stopping the spread of this virus.

The Indonesia government has also encouraged the citizens to obey some rules such as avoid public gatherings, wearing the mask, physical distancing, and some other measures [37]. The effectiveness of this rule itself needs to be further assessed in the next couple of months. However, as seen from the perspective in daily life, people disobey this rule with their reason, such as socio-economic conditions. Indeed, it was predicted that COVID-19 affects socio-economic in general, such as healthcare, business, government, and broader society [38]. Accordingly, the basic knowledge about COVID-19 transmission and the prevention measure is essential to be understood by the public for the rules to be effective.

In general, the respondent's total knowledge score is age-associated, with respondents aged 26-35 years have the highest score. We could assume 26-35-year-old would consist of currently pursuing their master's or even doctorate, and they might as well work. Therefore, they are mature enough to receive, understand, and deliver precise information about COVID-19 to the people surrounding them. This finding implies that this aged group is a potential change agent in public engagement by providing information to fight COVID-19. Identifying the best message carrier is a fundamental step to bring health promotion well accepted by the audience. One of the problems with managing COVID-19 is that much fake news contains misinformation and disinformation that has caused uncertainty within the community. This is also the case in Indonesia. There is news that underestimates COVID-19 as a disease with only a "flu-like illness" that is harmless or the emergence of claims of traditional medicines. These particular objects are over-claimed to be anti-COVID-19 drugs. In response to this, clarity, critical thinking, understanding, and maturity are needed in receiving information and being careful in sharing information with others. The Indonesian government has established an Integrated Centre of Information for COVID-19, a body directly under the presidential office to centralized COVID-19-related information, from data and new clusters to progress, initiatives, and potential vaccines. The ongoing transmission of COVID-19 implies that public health practitioners must advocate the community about prevention measures, including in puskesmas (community health centres) setting that plays a crucial role at the forefront of health promotion programs.

Our research may have a limitation as we collected the data online; therefore, it is impossible to control for self-reporting answers and potential misinterpreted questions. Besides the limitation, our research also has an excellent response from universities in $70 \%$ of the province in Indonesia, meaning that we can assume the respondent represents Indonesia. This study discovered, although the respondent has a basic COVID-19 knowledge and the proper attitude, it seems they were not consistently complying with some particular measures. The gap between knowledge and practice should be addressed accordingly, for instance, between transmission and social distancing by staying at home. Education about COVID-19 literacy should be scaled up by engaging the potential message carrier to influence society. Previous studies explained the significant association between knowledge and compliance on undertaking social distancing among students in Jakarta. It found that as many as $59.4 \%$ of students who have good knowledge of physical distancing have good physical distancing behavior with 1.7 times better than those who have insufficient knowledge [39]. 


\section{CONCLUSION}

The findings of this study reflect the need to remind young adults of the population's at-risk behaviour. Several regions have introduced rules, such as compulsory mask use and standard operating procedures, while using public transportation outside the city, such as trains and planes. Efforts to improve COVID-19 prevention actions, in addition to increasing awareness, will include strong will and leadership by enforcing regulations that provide guidelines and punishments in the event of a violation. Several publications mention an increase in compliance with health behaviour with the implementation of rules. This also indicates the seriousness and commitment of the government in controlling the transmission of COVID19. This research further stresses the role of social media and the web in accessing COVID-19-related reference knowledge as the primary outlet for young adult age groups. Using social media and the internet as sources of information is helpful for the government or health institutions to provide relevant information with different exciting media.

\section{ACKNOWLEDGEMENTS}

The authors would like to thank those who participated in this survey and Ineu Firia Dewi, who assisted with this study. This research was funded by the Universitas Ahmad Dahlan, Indonesia, with an ID contract (PD-172/SP3/LPPM-UAD/2020)

\section{REFERENCES}

[1] WHO, "WHO Coronavirus Disease (COVID-19) Dashboard," Web, 2021, [Online]. Available: https://covid19.who.int/ (accessed Jan. 31, 2021).

[2] Indonesia task force for acceleration of covid handling, "Infografis COVID-19 (1 Mei 2020)," Web, 2020, [Online]. Available: https://covid19.go.id/p/berita/infografis-COVID-19-1-mei-2020 (accessed May 02, 2020).

[3] WHO, “Coronavirus Disease 2019," Web Page, 2020, [Online]. Available: https://www.who.int/docs/defaultsource/coronaviruse/situation-reports/20200423-sitrep-94-COVID-19.pdf?sfvrsn=b8304bf0_4 (accessed Aug. 19, 2020).

[4] V. M. Corman et al., "Evidence for an Ancestral Association of Human Coronavirus 229E with Bats," J. Virol., vol. 89, no. 23, pp. 11858-11870, 2015, doi: 10.1128/jvi.01755-15.

[5] H. Harapan et al., "Coronavirus disease 2019 (COVID-19): A literature review," J. Infect. Public Health, vol. 13, no. 5, pp. 667-673, 2020, doi: 10.1016/j.jiph.2020.03.019.

[6] W. J. Wiersinga, A. Rhodes, A. C. Cheng, S. J. Peacock, and H. C. Prescott, "Pathophysiology, Transmission, Diagnosis, and Treatment of Coronavirus Disease 2019 (COVID-19)," JAMA-Journal Am. Med. Assoc., vol. July, no. $12839,2020$.

[7] S. Pappas, "What are the symptoms of COVID-19?," Live Science, 2020, [Online]. Available: https://www.livescience.com/coronavirus-symptoms.html (accessed May 10, 2020).

[8] M. Cascella, M. Rajnik, A. Cuomo, S. C. Dulebohn, and R. Di Napoli, "Features, Evaluation and Treatment Coronavirus (COVID-19," StatPearls, 2020.

[9] WHO, "Coronavirus disease 2019 (COVID-19): Situation Report," Switzerland, 2020, [Online]. Available: https://www.who.int/docs/default-source/coronaviruse/situation-reports/20200326-sitrep-66-COVID-19.pdf. (Accessed: May 10, 2020).

[10] WHO Indonesia, "Questions and answers regarding Coronavirus," Web page, 2020, [Online]. Available: https://www.who.int/indonesia/news/novel-coronavirus/qa-for-public (accessed May 02, 2020).

[11] WHO, "Rolling updates on coronavirus disease (COVID-19)," Web Page, 2020, [Online]. Available: https://www.who.int/emergencies/diseases/novel-coronavirus-2019/events-as-they-happen (accessed May 02, 2020).

[12] O. Dyer, "COVID-19: Airborne transmission is being underestimated, warn experts," BMJ, vol. 370, no. July, p. m2720, 2020, doi: 10.1136/bmj.m2720.

[13] L. Setti et al., "Airborne transmission route of COVID-19: Why 2 meters/6 feet of inter-personal distance could not be enough," Int. J. Environ. Res. Public Health, vol. 17, no. 8, pp. 1-6, 2020, doi: 10.3390/ijerph17082932.

[14] WHO Indonesia, "Coronavirus Disease 2019 (COVID-19) Situation Report-1," Jakarta, Mar. 2020, [Online]. Available: https://www.who.int/docs/default-source/searo/indonesia/covid19/who-indonesia-situation-report1.pdf?sfvrsn=6be5b359_0.( Accessed: Aug. 23, 2020).

[15] S. Sulistyawati et al., "Knowledge, Attitudes, Practices and Information Needs During the COVID-19 Pandemic in Indonesia," Risk Manag. Healthc. Policy, vol. 14, pp. 163-175, 2021, [Online]. Available: https://www.dovepress.com/articles.php?article_id=61222.

[16] L. Huang et al., "Rapid asymptomatic transmission of COVID-19 during the incubation period demonstrating strong infectivity in a cluster of youngsters aged 16-23 years outside Wuhan and characteristics of young patients with COVID-19: A prospective contact-tracing study," J. Infect., vol. 80, no. 6, pp. e1-e13, 2020, doi: 10.1016/j.jinf.2020.03.006.

[17] M. Cohut, "COVID-19: Over $80 \%$ of young people may show no symptoms," Medical News Today, 2020, [Online]. Available: https://www.medicalnewstoday.com/articles/COVID-19-over-80-of-young-individuals-mayshow-no-symptoms\#1 (accessed Jun. 29, 2021). 
[18] N. G. Davies, P. Klepac, Y. Liu, K. Prem, M. Jit, and R. M. Eggo, “Age-dependent effects in the transmission and control of COVID-19 epidemics," Nat. Med., vol. 26, no. August, pp. 1205-1211 2020, doi: 10.1038/s41591-0200962-9.

[19] B. Blomberg et al., "Long COVID in a prospective cohort of home-isolated patients," Nat. Med., 2021, doi: 10.1038/s41591-021-01433-3.

[20] L. Chadwick and I. Kumar, "Coronavirus: Young people are not invincible to COVID-19 effects, warns WHO chief | Euronews," Euronews, 2020, [Online]. Available: https://www.euronews.com/2020/07/30/coronavirusgreater-numbers-of-young-europeans-are-contracting-COVID-19-says-who (accessed Aug. 15, 2020).

[21] C. Sayavong, J. Chompikul, S. Wongsawass, and C. Rattanapan, "Knowledge, attitudes and preventive behaviors related to dengue vector breeding control measures among adults in communities of Vientiane, capital of the Lao PDR," J. Infect. Public Health, vol. 8, no. 5, pp. 466-73, 2015, doi: 10.1016/j.jiph.2015.03.005.

[22] W. N. De Araújo et al., "Knowledge, attitudes, and practices related to leptospirosis among urban slum residents in Brazil," Am. J. Trop. Med. Hyg., vol. 88, no. 2, pp. 359-363, 2013, doi: 10.4269/ajtmh.2012.12-0245.

[23] WHO, "Implementation of Integrated Vector Management Regional Office for South-East Asia," Chiang Mai, 2010, [Online]. Available: http://apps.searo.who.int/PDS_DOCS/B4687.pdf.

[24] A. Itrat et al., "Knowledge, Awareness and Practices Regarding Dengue Fever among the Adult Population of Dengue Hit Cosmopolitan," PLoS One, vol. 3, no. 7, pp. 1-6, 2008, doi: 10.1371/journal.pone.0002620.

[25] P. Douglas et al., "Hydration : Knowledge, Attitudes , and Practices of UK Dietitians," J. Biomed. Educ., vol. 2015, pp. 1-6, 2015.

[26] I. Nirmala, A. N. R. Attamimi, and V. E. Alami, Higher Education Statistics 2018. Jakarta: Pusat Data dan Informasi Iptek Dikti, 2018.

[27] G. Smith, "Does gender influence online survey participation ?: A record-linkage analysis of university faculty online survey response behavior," ERIC Doc. Reprod. Serv., vol. 501717, 2008.

[28] WHO, "Coronavirus," Web Page, 2020, [Online]. Available: https://www.who.int/healthtopics/coronavirus\#tab=tab_1 (accessed Apr. 09, 2020).

[29] UNICEF Romania, "The COVID-19 pandemic shows how much we rely on vaccines to save lives | UNICEF Romania,"Web, 2020, [Online]. Available: https://www.unicef.org/romania/stories/COVID-19-pandemic-showshow-much-we-rely-vaccines-save-lives (accessed May 10, 2020).

[30] J. F. W. Chan et al., "A familial cluster of pneumonia associated with the 2019 novel coronavirus indicating person-to-person transmission: a study of a family cluster," Lancet, vol. 395, no. 10223, pp. 514-523, Feb. 2020, doi: 10.1016/S0140-6736(20)30154-9.

[31] WHO, "Modes of transmission of virus causing COVID-19: implications for IPC precaution recommendations," Web Page, 2020, [Online]. Available: https://www.who.int/news-room/commentaries/detail/modes-oftransmission-of-virus-causing-COVID-19-implications-for-ipc-precaution-recommendations (accessed May 10, 2020).

[32] C. L. Jones, J. D. Jensen, C. L. Scherr, N. R. Brown, K. Christy, and J. Weaver, "The Health Belief Model as an Explanatory Framework in Communication Research: Exploring Parallel, Serial, and Moderated Mediation Christina," Health Commun., vol. 30, no. 6, pp. 566-576, 2015, doi: 10.1080/10410236.2013.873363.The.

[33] S. Sulistyawati, S. A. Mulasari, and T. W. Sukesi, "Teenager and Climate Change Communication," Int. J. Sci. Technol. Res., vol. 8, no. 10, pp. 904-908, 2019.

[34] C. L. Ventola, "Social Media and Health Care Professionals: Benefits, Risks, and Best Practices," $P \& T$, vol. 39, no. 7, pp. 491-500, 2014.

[35] WHO Eastern Mediterranean, "Engaging young people in the response to COVID-19 in WHO's Eastern Mediterranean Region," Web Page, 2020, [Online]. Available: http://www.emro.who.int/media/news/engagingyoung-people-in-the-response-to-COVID-19-in-whos-eastern-mediterranean-region.html (accessed Aug. 19, 2020).

[36] S. Dryhurst et al., "Risk perceptions of COVID-19 around the world," J. Risk Res., vol. 23, no. 7-8, pp. 994-1006, 2020, doi: 10.1080/13669877.2020.1758193.

[37] R. Djalante et al., "Review and analysis of current responses to COVID-19 in Indonesia: Period of January to March 2020,” Prog. Disaster Sci., vol. 6, p. 100091, 2020, doi: 10.1016/j.pdisas.2020.100091.

[38] M. Nicola et al., The Socio-Economic Implications of the Coronavirus and COVID-19 Pandemic: A Review. IJS Publishing Group Ltd, 2020.

[39] M. H. E. M. Browning et al., "Psychological impacts from COVID-19 among university students: Risk factors across seven states in the United States," PLoS One, vol. 16, no. 1, pp. 1-27, 2021, doi: 10.1371/journal.pone.0245327. 